\title{
A CONTRIBUTION TO AN INVENTORY OF LICHENS FROM SOUTH SISTER, NORTHEASTERN TASMANIA
}

\author{
by G. Kantvilas, J. A. Elix and S. J. Jarman
}

(with five plates and one appendix)

\begin{abstract}
Kantvilas, G., Elix, J.A. \& Jarman, S.J. 2008 (28:xi): A contribution to an inventory of lichens from South Sister, northeastern Tasmania. P'apers and Proceedings of the Royal Society of Tasmania 1.42(2): 49-60. https://doi.org/10.26749/rstpp.142.2.49

ISSN 0080-4703. Tasmanian Herbarium, Private Bag 4, Hobart, Tasmania 7001, Australia (GK*, SJJ); Department of Chemistry, Australian National University, Canberra, ACT 0200, Australia (JAE). *Author for correspondence.
\end{abstract}

\begin{abstract}
A lichen survey at South Sister, northeastern Tasmania, has yielded 234 taxa. The following 16 are recorded from Tasmania for the first time: Acarospora veronensis A. Massal., Arthothelium macounii (G. Merr.) W.J. Noble, Austrolecia antarctica Hertel, Bacidia wellingtonii (Stirt.) D.J. Galloway, Buellia griseovirens (Turner \& Borrer ex Sm.) Almb., Coccocarpia pellita (Ach.) Müll. Arg., Hafellia subcrassata Pusswald, H. xanthonica Elix, Hypocenomyce scalaris (Ach.) M. Choisy, Illosporium carneum Fr., Lecidella pruinosula (Müll. Arg.) Kantvilas \& Elix comb. nov., Lecidella sublapicida (Knight) Hertel, Lepraria eburnea J.R. Laundon, Micarea denigrata (Fr.) Hedl., Mycoblastus campbellianus (Nyl.) Zahlbr. and Mycoporum antecellens (Nyl.) R.C. Harris. The survey represents the first of its kind for any dolerite peak in Tasmania, and serves as a benchmark for future studies. Aspects of the distribution and ecology of the flora, the occurrence of rare, threatened or otherwise unusual species, and significant range extensions are discussed. The effect of metal-rich run-off from galvanised structures is identified as a potential threat to the flora values of the site.
\end{abstract}

Key Words: biodiversity, dolerite, flora, Lecidella, lichenised fungi.

\section{INTRODUCTION}

South Sister $\left(41^{\circ} 32^{\prime} \mathrm{S} 148^{\circ} 10^{\prime} \mathrm{E}\right)$ is a small dolerite pinnacle about $800 \mathrm{~m}$ a.s.l. in northeast Tasmania, overlooking the settlement of St Marys. Located within State Forest, the peak is a popular vantage point for bushwalkers, rockclimbers and naturalists, as well as being the site for several telecommunications installations. A proposal (in 2005) to harvest timber from a coupe on its southern slopes generated intense interest in the area, as well as considerable opposition from members of the local community. The campaign against logging led to the compilation of extensive data on various aspects of the area, including its natural history. The history of the campaign and much of this information is available at http://www.southsister.org.

As part of the study of the natural history of South Sister, a survey of lichens was conducted, revealing a diverse and interesting flora, rich in seldom-encountered species. In view of the paucity of sound inventory data for lichens for much of Tasmania, we present our results here to serve as a benchmark for future lichen surveys of Tasmania's peaks, and as a permanent record of the many significant species recorded.

\section{METHODS}

Fieldwork was conducted by GK and JAE on 10-11 November 2004, and by GK and SJJ on 31 August 2006 and 22 November 2007. The proposed logging coupe was examined although most effort was concentrated on the pinnacle and its immediate environs. Work was conducted within a broad band from the car park at $750 \mathrm{~m}$ a.s.l., along the walking track to the pinnacle, on the scree slopes of the pinnacle itself, and along the small rock-climbers' tracks on the slopes that lead to numerous rocky tors. A preliminary overview identified the following major lichen habitats: wet scrub, rock scree, large cliffs and tors, eucalypt woodland and relict rainforest (pls 1-2). The subsequent lichen survey was structured around this classification.

Collections were made of all species for identification or confirmation of identification in the laboratory. Identification involved morphological examination, anatomical examination using high-power microscopy, chemical analyses using standard methods (Orange et al. 2001) and comparison with reliably identified herbarium reference specimens. Vouchers of all species recorded are housed at the Tasmanian Herbarium ( $\mathrm{HO})$, with some additional material at the Centre for Plant Biodiversity Research in Canberra (CANB). For taxa not identified to species rank, a reference specimen number (e.g., GK 300/06) is provided in parentheses in appendix 1.

Species nomenclature follows McCarthy (2008). Nomenclature of ascus types follows Hafellner (1984).

\section{RESULTS}

\section{Overview of the vegetation}

The upper slopes of South Sister carry open forest dominated by Eucalyptus delegatensis R. Baker. The eucalypts become shorter and more widely dispersed towards the pinnacle and the taller understorey shrubs and trees become increasingly prominent, and dominate where the eucalypts are absent. The most common of these species are Bedfordia salicina (Labill.) DC., Tasmannia lanceolata (Poiret) A.C. Smith, Notelaea ligustrina Vent. and Pittosporum bicolor Hook. Several smaller shrubs, including Cyathodes glauca Labill., Oxylobium ellipticum (Labill.) R. Br. and Olearia stellulata (Labill.) DC., are also common. Ferns, mainly Polystichum proliferum (R. Br.) C. Presl and Microsorum pustulatum (Forst.f.) Copel. on the pinnacle itself, occur below the small trees and shrubs, or in sheltered spots among the rocks. Grasses are locally common in open areas. One very small patch of relict rainforest, dominated by a few trees of Atherosperma 


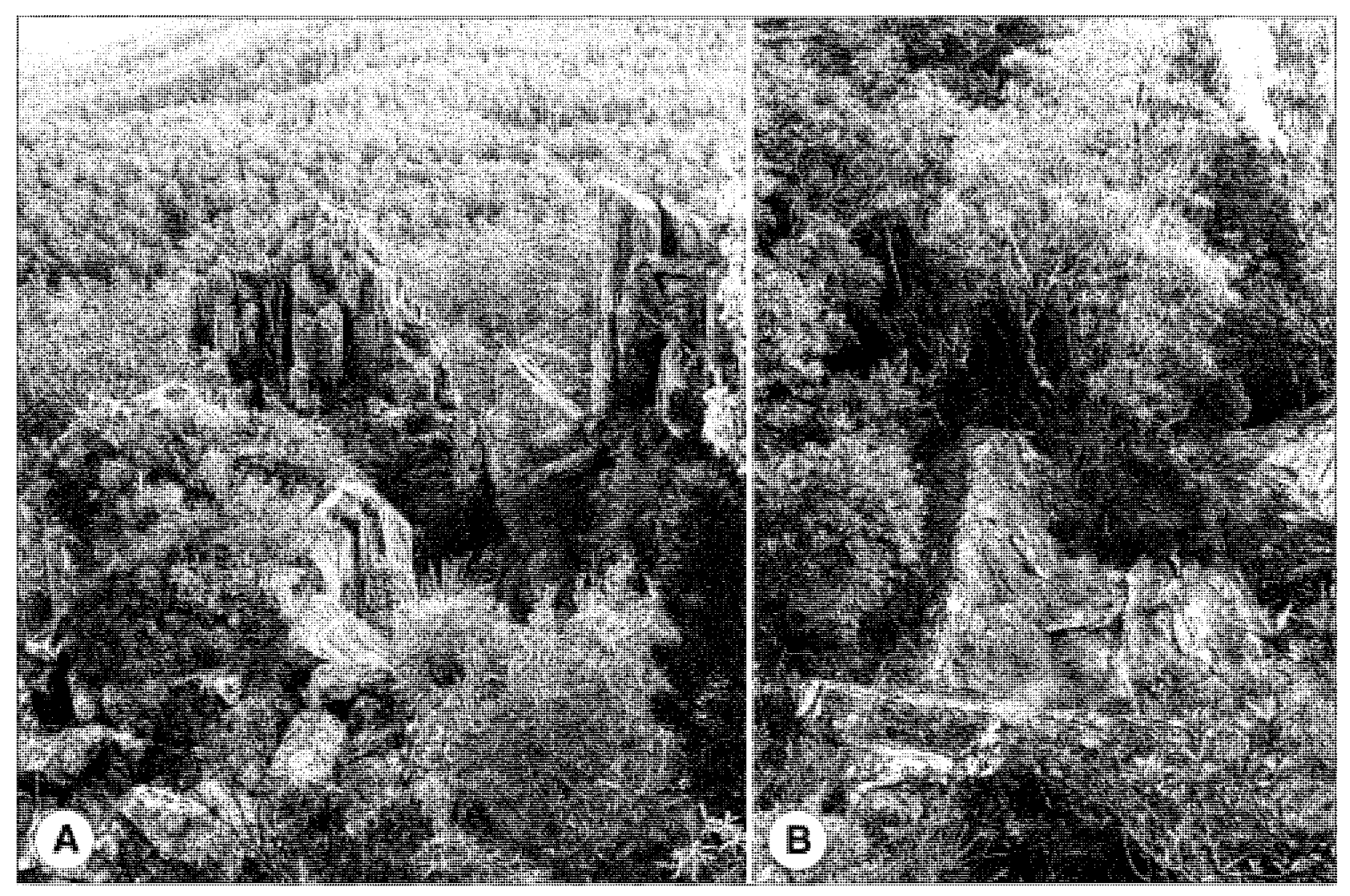

PLATE 1

Vegetation of South Sister. (A) Dolerite tors emergent from wet scrub, with open eucalypt forest on the lower slopes (background). (B) Dense wet scrub on a scree of large dolerite boulders.

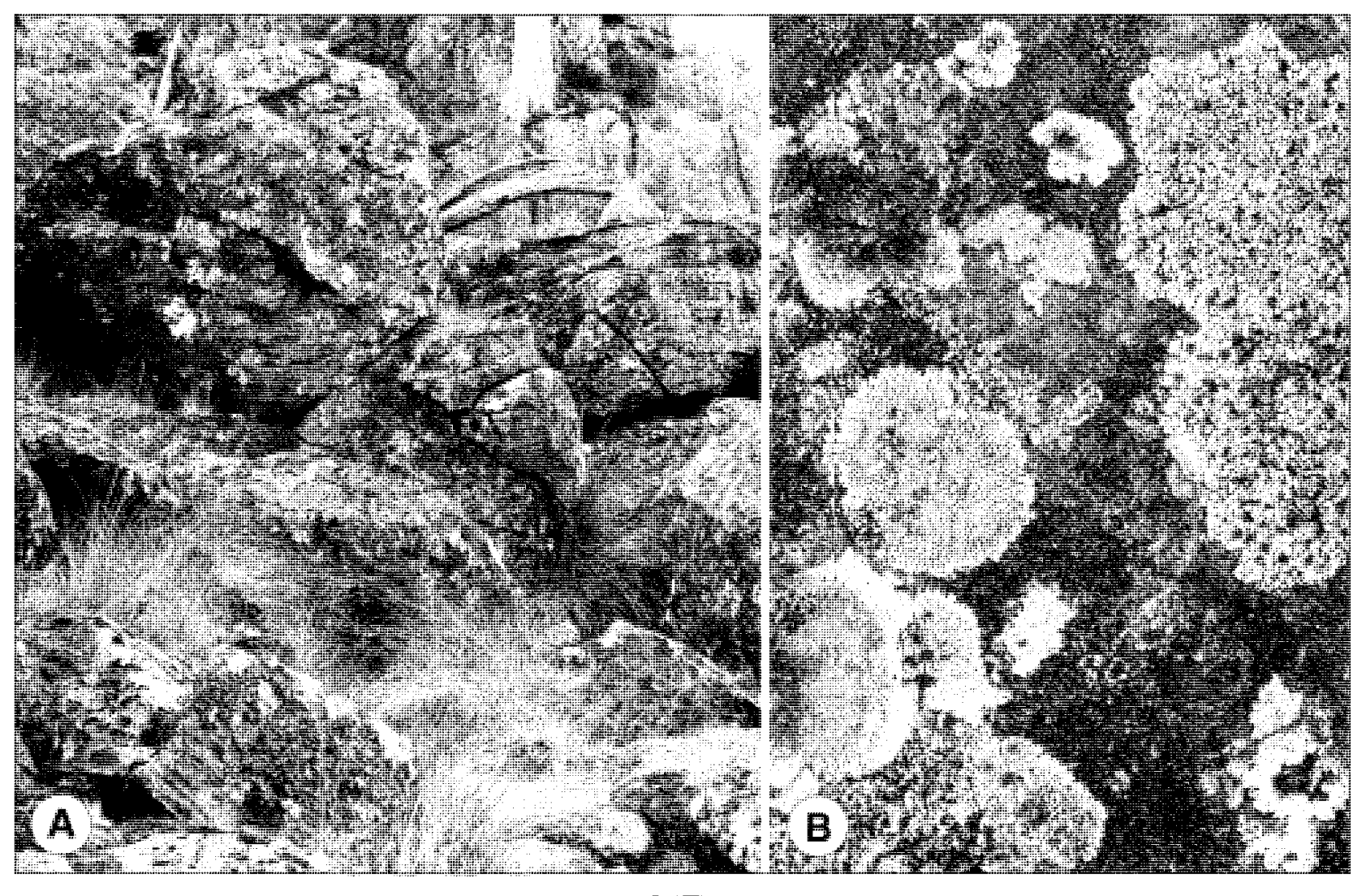

PLATE 2

(A) Dolerite boulders, colonised by a highly diverse lichen flora. (B) Detail of lichen mosaics on dolerite; the dominant species shown here belong to the genus Placopsis. 
moschatum Labill., occurs in a relatively fire-protected area on the south side of the pinnacle.

Everywhere on and around the pinnacle the land surface is rocky, limiting the extent and density of the woody plant layer and ensuring plenty of light reaches the ground surface. In more sheltered situations, below overhanging rocks or under a sparse vegetation canopy, the surfaces of rocks, soil and living stems carry a rich flora of mosses, liverworts and lichens, creating an image of lush abundance. Even in exposed sites, on the brightly lit, sloping or vertical rock surfaces where conditions are unfavourable for many bryophytes, the diversity and abundance of lichens remain high.

\section{Lichen inventory}

In all, 234 lichen taxa were recorded (appendix 1). This figure includes 16 species that are recorded for Tasmania for the first time; diagnoses, notes and lists of reference specimens for these are given below. Two species new to science were discovered during the survey and have been published elsewhere: Punctelia transtasmanica Elix \& Kantvilas, also known from Flinders Island and New Zealand (Elix \& Kantvilas 2005), and Trapelia lilacea Kantvilas \& Elix, widespread on dolerite in the Tasmanian highlands (Kantvilas \& Elix 2007); the latter has since been recorded in New Zealand (D.J. Galloway, pers. comm.). Additional new species are likely to be present amongst the, as yet, not fully identified material, but await future study.

\section{New records}

\section{Acarospora veronensis A. Massal., Ric. Auton. Lich. Crost.: 29 (1852)}

Thallus areolate, reddish brown; areoles plane to convex to somewhat bullate, dispersed or contiguous, $0.5-1 \mathrm{~mm}$ wide, rounded to \pm rhomboid; apothecia $1-3$ per areole, $0.1-0.5$ $\mathrm{mm}$ wide, rather sunken and crater-like, with a concave, reddish or blackish brown disc; hymenium $60-100 \mu \mathrm{m}$ thick; ascospores very numerous in the ascus, $3-5 \times 1.5-2$ $\mu \mathrm{m}$. Containing no substances detectable by t.l.c. See Purvis \& James (1922) for more details.

At South Sister, this species occurred very abundantly on dolerite rock plates where zinc-rich run-off from galvanised sheds and fences has cleared the rock surface of almost all "naturally-occurring" lichens. In this unusual habitat, it is associated with Candelariella vitellina and Lecanora polytropa. Elsewhere in Tasmania, it has been found in nutrient-enriched sites (from human urine) such as occur around shelter huts in bushwalking areas.

Specimens examined: TASMANIA: South Sister near summit, $41^{\circ} 32^{\prime} \mathrm{S} 148^{\circ} 10^{\prime} \mathrm{E}, 800 \mathrm{~m}$ alt., 31.viii.2006, $G$. Kantvilas 339/06 (HO); Rodway Range at Tarn Shelf hut, $42^{\circ} 41^{\prime S} 146^{\circ} 34^{\prime} \mathrm{E}, 1250 \mathrm{~m}$ alt., 28.x.2007, G. Kantvilas $324 / 07(\mathrm{HO})$.

\section{Arthothelium macounii (G. Merr.) W.J. Noble, Mycotaxon 28: 91 (1987)}

Thallus immersed to absent; fruiting bodies arthonioid, $0.2-0.5 \mathrm{~mm}$ wide, roundish, convex, basally constricted; hymenium orange-yellow with numerous reddish brown granules, $\mathrm{K}+$ vivid magenta; ascospores broadly ellipsoid, at first hyaline, soon becoming grey-brown, 29-32 × 11-15 $\mu \mathrm{m}$, macrocephalic, with a prominent terminal, undivided cell and a muriform "tail" having 3-5 transverse and 0-2 longitudinal septa. See Coppins \& James (1979) as Arthothelium ilicinum var. reagens ( $=A$. macounii) for further details.

The Tasmanian specimens are from sheltered underhangs on dolerite in wet scrub. The discovery in Tasmania of this uncommon species, previously known only from western Scotland and British Columbia, represents a remarkable range extension. Superficially the Tasmanian specimens differ from typical material by their saxicolous habitat (elsewhere this species is an epiphyte) and the rather convex, almost subglobose fruiting bodies (normally these are flat and adnate); however, the latter feature may be interpreted as a function of the habitat. Anatomically, the similarity of the Tasmanian specimens to northern hemisphere material is unequivocal. There is another, as yet undescribed Arthothelium species in Tasmania that also displays an identical $\mathrm{K}+$ magenta reaction in the fruiting bodies, but this differs by having larger ascospores $(38-43 \times 18-20 \mu \mathrm{m})$ that are ellipsoid and muriform throughout.

Specimens examined: TASMANIA: South Sister, $41^{\circ} 32^{\prime} \mathrm{S}$ $148^{\circ} 10^{\prime} \mathrm{E}, 750 \mathrm{~m}$ alt., 10.xi.2004, G. Kantvilas $431 / 04$ \& J.A. Elix (HO); Hartz Mountains, iii.1963, P.W. James (HO).

\section{Austrolecia antarctica Hertel, Beih. Nova Hedwigia 79: 453 (1984)}

Thallus crustose, bullate-areolate, white-grey to cream-white; areoles to $3 \mathrm{~mm}$ wide, mostly with a minutely roughened surface; apothecia lecideine, black, irregularly to $1.5 \mathrm{~mm}$ wide, broadly adnate, sometimes nestled deeply amongst the areoles; epihymenium green, unchanged in $\mathrm{K}$; hypothecium purplebrown, unchanged in K; asci approximating the Catillariatype (sensu Hafellner 1984), with a well-developed amyloid tholus lacking discernible internal structures; paraphyses very robust, 3-4 $\mu \mathrm{m}$ wide, simple or occasionally bifurcate or anastomosing, with apices unpigmented and not markedly expanded; ascospores hyaline, ellipsoid to \pm oblong, simple to 1 -septate, $11-19 \times 4-7 \mu \mathrm{m}$. Containing atranorin $( \pm)$, norstictic and connorstictic acids; microscope preparations of the thallus produce red, needle-like crystals with the addition of $\mathrm{KOH}$. See Rambold (1989) for further details.

This saxicolous species is also known from the Antarctic Peninsula, South Shetland Islands and mainland Australia (Rambold 1989, Ovstedal \& Lewis-Smith 2001). With its conspicuous thallus of bullate areoles, it is easily detected in the field, although there are some, as yet unidentified, superficially similar species growing in identical habitats in the Tasmanian flora. Anatomically it is best identified by its Catillaria-type asci and 0-1-septate ascospores. It grows on exposed boulders and is likely to be more widespread in alpine areas but rarely collected.

Specimens examined: TASMANIA: South Sister, $41^{\circ} 32^{\prime} \mathrm{S}$ $148^{\circ} 10^{\prime} \mathrm{E}, 780 \mathrm{~m}$ alt., 22.xi.2007, G. Kantvilas 357/07 (HO); The Knuckle, $1400 \mathrm{~m}$ alt., 8.iv.1996, G. Kantvilas $4 / 96$ (HO).

\section{Bacidia wellingtonii (Stirt.) D.J. Galloway, New Zealand J. Bot. 21: 192 (1983)}

Thallus crustose, effuse, whitish or greenish grey; apothecia basally constricted, superficial, mostly to $0.6 \mathrm{~mm}$ wide, with a black, plane disc and pale red-brown margin; epihymenium green, \pm unchanged in $\mathrm{K}, \mathrm{N}+$ vivid lilac; ascospores very tightly coiled in the ascus, filiform, tapering towards one end, 50-60 × 3-4 $\mu \mathrm{m}$, up to 15-septate. See Galloway (1985) for full description.

The genus Bacidia is well represented in Tasmania but most species remain unidentified pending a detailed study of 
the group. Bacidia wellingtonii is characterised by the green epithecium and the tightly coiled ascospores. In Tasmania, it occurs on smooth bark in shade in wet forest. It is also known from New Zealand.

Specimens examined: TASMANIA: South Sister, $41^{\circ} 32^{\prime} \mathrm{S}$ 148 10'E, $750 \mathrm{~m}$ alt., 31.viii.2006, G. Kantvilas 313/06 (HO); Simons Road near Ben Nevis, $830 \mathrm{~m}$ alt., 7.xii.1981, G. Kantvilas 1084/81 (BM, HO).

\section{Buellia griseovirens (Turner \& Borrer ex Sm.) Almb., Bot. Not. 1952: 247 (1952)}

Thallus crustose, greyish white, sorediate; soralia discrete and roundish, to $0.7 \mathrm{~mm}$ wide, sometimes becoming confluent, concolorous with the thallus or pale to dark greenish grey; apothecia black, lecideine, to $1 \mathrm{~mm}$ wide, with disc mostly plane and margin persistent; hymenium lacking oil droplets; asci 8-spored; ascospores grey-brown to dark brown, ellipsoid, $18-26 \times 10-12 \mu \mathrm{m}$, submuriform, with 1-3 transverse and $0-1$ longitudinal septa. Containing atranorin and norstictic acid; thallus $\mathrm{P}_{+}$orange, $\mathrm{K}+$ yellow red. See Orange et al. (1992) and Nordin (2000) for further descriptions.

This is a cosmopolitan temperate species that is relatively common in Tasmania in open woodlands where it occurs on bark or wood. Understorey trees such as Banksia marginata Cav, are a particularly favoured host. When fertile, the brown, submuriform ascospores are diagnostic. Sterile specimens can be determined by their chemical composition. Superficially similar, sorediate species include Trapeliopsis flexuosa (which is $\mathrm{C}+\mathrm{red}$ ) and Catillochroma pulverea (which is $\mathrm{K}-, \mathrm{P}+\mathrm{red}$ ).

Specimens examined: TASMANIA: E of Lake Leake, $42^{\circ} 01^{\prime} \mathrm{S} 147^{\circ} 55^{\prime} \mathrm{E}, 400 \mathrm{~m}$ alt., 24.iv.1996, G. Kantvilas s.n. (HO); South Sister, 41 $32^{\circ} \mathrm{S} 148^{\circ} 10^{\prime} \mathrm{E}, 750 \mathrm{~m}$ alt., 10.xi.2004, G. Kantvilas 287/04 \& J.A. Elix (HO); W of New Norfolk along Glenora Road, $42^{\circ} 47^{\prime} \mathrm{S} 147^{\circ} 02^{\prime} \mathrm{E}, 90 \mathrm{~m}$ alt., 19.ii.1997, G. Kantvilas 54197 (HO); $1 \mathrm{~km} \mathrm{~N}$ of Lake Ironstone, $41^{\circ} 42^{\prime} \mathrm{S} 146^{\circ} 28^{\prime} \mathrm{E}, 1190 \mathrm{~m}$ alt., 20.xi.2005, G. Kantvilas 335/05 (HO); $2 \mathrm{~km} \mathrm{~N}$ of Stonehurst Sugarloaf, $42^{\circ} 31^{\prime} \mathrm{S} 147^{\circ} 48^{\prime} \mathrm{E}, 350 \mathrm{~m}$ alt., 17.vi.2003, G. Kantvilas $348 / 03(\mathrm{HO})$.

\section{Coccocarpia pellita (Ach.) Müll. Arg. emend. R.}

Sant., Symb. Bot. Upsal. 12(1): 420 (1952)

Thallus foliose, lead-grey, with lobes flabellate, broadly rounded, 1-5 mm wide; isidia flattened to squamulose, laminal and marginal; underside pale brown, with dense, pale to dark brown rhizines; apothecia lecideine, black, plane to undulate, to $3 \mathrm{~mm}$ wide. See Arvidsson (1983) for full description.

This is a widespread tropical to subtropical species. In Tasmania, its most southerly occurrence, it occurs on rocks in sclerophyll forest. The morphology of the isidia readily distinguishes this species from two other, superficially similar members of the genus present in Tasmania; that is, the common C. palmicola (with terete isidia) and the rare C. erythroxyli (lacking isidia).

Specimens examined: TASMANIA: Mt Cameron, 405' $\mathrm{S}$ $147^{\circ} 56^{\prime} \mathrm{E}, 350 \mathrm{~m}$ alt., 22.iv.1997, G. Kantvilas $126 / 97 \mathrm{~d}$ J.A. Elix (HO); Little Beach, $41^{\circ} 38^{\prime} \mathrm{S} 148^{\circ} 19^{\prime} \mathrm{E}, 10 \mathrm{~m}$ alt., 19.ii.2001, G. Kantvilas 312/01 (HO); South Sister, $41^{\circ} 32^{\prime} \mathrm{S}$ $148^{\circ} 10^{\prime} \mathrm{E}, 800 \mathrm{~m}$ alt., 10.xi.2004, G. Kantvilas 308/04 \& J.A. Elix (HO); St Patricks Head, 41 $1^{\circ} 35^{\prime}$ S 148 $18^{\circ} \mathrm{E}$, 7.vii.1973, G.C. Bratt 73/660 (HO); c. $1 \mathrm{~km} \mathrm{NE}$ of Coles Bay, 42 07'S $148^{\circ} 17^{\prime} \mathrm{E}, 100-110 \mathrm{~m}$ alt., 23.iv.2007, $G$. Kantvilas 182/07 (HO).
Hafellia subcrassata Pusswald in Marbach, Biblioth. Lich. 74: 284 (2000)

Thallus crustose, greyish white; apothecia black, lecideine, mostly to $1 \mathrm{~mm}$ wide, with disc plane to somewhat convex and margin persistent; epithecium brown, unchanged in $\mathrm{KOH}$; hymenium inspersed with oil droplets; asci 8-spored; ascospores brown to grey-brown, ellipsoid, 1-septate, $28-36 \times 12-14 \mu \mathrm{m}$, with relatively weak apical, subapical and septal thickenings and \pm \pm minutely roughened outer wall. Containing norstictic acid with traces of 4, 5-dichlorolichexanthone; microscope preparations of the thallus often develop red, needle-like crystals with the addition of $\mathrm{KOH}$. See Marbach (2000) for further details.

The genus Hafellia is well represented but rather poorly known in Tasmania, and much of the literature (e.g., Marbach 2000, Etayo \& Marbach 2003) makes scant reference to Tasmanian collections. The Tasmanian specimen is epiphytic on the bark of Cyathodes glauca. It grew together with the related $H$. babiana (Malme) Sheard, which is far more common and widespread in Tasmania, and has an identical thallus chemistry. That species differs from $H$. subcrassata chiefly by the presence of "sedifolia-grey" pigment (see Meyer \& Printzen 2000) in the epithecium; this pigment reacts $\mathrm{C}+\mathrm{K}+$ violet (Sheard 1992, Marbach 2000).

Specimen examined: TASMANIA: South Sister, $41^{\circ} 32^{\prime} \mathrm{S}$ $148^{\circ} 10^{\prime} \mathrm{E}, 750 \mathrm{~m}$ alt., 10.xi.2004, G. Kantvilas 367/04 \& J.A. Elix (HO).

Hafellia xanthonica Elix, Australas. Lichenol. 59: 36 (2006)

Thallus crustose, pale grey to yellowish grey; apothecia black, lecideine, mostly to $1.5 \mathrm{~mm}$ wide, with disc plane to somewhat convex and margin persistent; epithecium brown, unchanged in $\mathrm{KOH}$; hymenium inspersed with oil droplets; asci 8-spored, but sometimes with up to six ascopores aborted; ascospores brown to grey-brown, ellipsoid, 1-septate, $14-30(-35) \times 6-13(-15) \mu \mathrm{m}$, with apical and subapical thickenings. Containing 4, 5-dichlorolichexanthone. See Elix (2006) for further details.

Specimen examined: TASMANIA: southern slope of South Sister, $41^{\circ} 32^{\prime} \mathrm{S} 148^{\circ} 10^{\prime} \mathrm{E}, 640 \mathrm{~m}$ alt., 10.xi.2004, J.A.Elix 28694 \& G. Kantvilas (CANB).

\section{Hypocenomyce scalaris (Ach.) M. Choisy, Bull. Mens. Soc. Linn. Soc. Bot. Lyon 22: 103 (1953)}

Thallus squamulose; squamules to $1.5 \mathrm{~mm}$ wide, pale beige to yellowish, discrete, scattered or imbricate, with margins incised or crenulate, usually somewhat upturned, sorediate; apothecia mostly to $c .1 \mathrm{~mm}$ wide, brown to black, sometimes slightly bluish pruinose, with plane or undulate disc and persistent, flexuose margin. Containing lecanoric acid; squamules C+ red. See Timdal (1984) for full description.

This species is widespread in temperate areas in both hemispheres, and has been recorded throughout the Australian mainland (McCarthy 2008). Like other members of the genus, it is typically found on eucalypt wood or bark. The presence of soredia distinguishes it from the closely related, very common $H$. australis that occurs in identical habitats.

Specimens examined: TASMANIA: southern slope of South Sister, $41^{\circ} 32^{\prime} \mathrm{S} 148^{\circ} 10^{\prime} \mathrm{E}, 640 \mathrm{~m}$ alt., 10.xi.2004, G. Kantvilas 381104 \&. J. Elix (HO); E of Lake Leake, $42^{\circ} 01^{\prime} \mathrm{S} 147^{\circ} 55^{\prime} \mathrm{E}, 400 \mathrm{~m}$ alt., 24.iv. 1996, G. Kantvilas s.n. (HO); W of New Norfolk along Glenora Road, $42^{\circ} 47^{\prime} \mathrm{S}$ $147^{\circ} 02^{\prime} \mathrm{E}, 90 \mathrm{~m}$ alt., 19.ii.1997, G. Kantvilas $49 / 97$ (HO); 
The Hazards near Wineglass Bay Lookout, 4209'S $148^{\circ} 17^{\prime} \mathrm{E}$, $180 \mathrm{~m}$ alt., 19.vii.2005, G. Kantvilas 180/05 (HO); W of Tahune Bridge, $43^{\circ} 06^{\prime} \mathrm{S} 146^{\circ} 41^{\prime} \mathrm{E}, 120 \mathrm{~m}$ alt., 2.v.2006, G. Kantvilas 212/06 (HO).

IIlosporium carneum Fr., Syst. Mycol. 3: 259 (1822) This is a licheniciolous fungus growing on the thallus of Peltigera species, recognised by its bright orange conidiomata to c. $0.5 \mathrm{~mm}$ wide. See Hawksworth (1981) for further data.

Specimen examined: TASMANIA: South Sister, $41^{\circ} 32^{\prime} \mathrm{S}$ $148^{\circ} 10^{\prime} \mathrm{E}, 640 \mathrm{~m}$ alt., 10.xi.2004, G. Kantvilas 390/04 \&o J.A. Elix (CANB, GZU, HO).

\section{Lecidella pruinosula (Müll. Arg.) Kantvilas \& Elix comb. nov.}

Basionym: Lecidea pruinosula Müll. Arg., Flora 65:486(1882). Type: Australia: New South Wales, corticola ad Twofold Bay, T. White (holotype: G!).

= Lecidea cerarufa (Shirley) Zahlbr., Cat. Lich. Univ. 3: 746 (1925); Biatora cerarufa Shirley, Pap. \& Proc. Roy. Soc. Tasmania 1893: 217 (1894). Type: Australia: Tasmania, on bark, Bower Track, Mt Wellington, W.A. Weymouth 141 (holotype: BRI!).

Thallus crustose, creamish white, thin, smooth or somewhat scurfy, often rather patchy, diffuse; apothecia lecideine, $0.3-1 \mathrm{~mm}$ diam., with disc pale pink, orange or reddish brown, usually whitish grey-pruinose, at least when young, typically persistently plane and only rarely becoming convex with age; margin persistent, typically elevated above the level of the disc, with the rim pale orange to brown and the sides usually much paler, in section composed of radiating hyphae inspersed with crystals that fluoresce in polarised light but do not dissolve in $\mathrm{KOH}$; hypothecium (30-)80-110 $\mu \mathrm{m}$ thick, colourless to pale yellowish; hymenium $80-110 \mu \mathrm{m}$ thick, colourless, with a red-brown epithecial layer composed of granules that do not dissolve in $\mathrm{KOH}$; asci 8-spored, 55-70 × 14-24 $\mu \mathrm{m}$, of the Lecanoratype but with the masse axiale \pm barrel-shaped; paraphyses $1.5-2 \mu \mathrm{m}$ thick, wavy, simple to very sparingly branched, rather coherent in water, not capitate; ascospores hyaline, broadly ellipsoid, ovate to sometimes almost subglobose, (12-) 14-18(-20) $\times(8-) 10-14 \mu \mathrm{m}$. Chemistry: pannarin $( \pm$ minor), dechloropannarin ( \pm minor), norpannarin ( \pm trace), 3-O-methylthiophanic acid ( \pm major), 2,5,7-trichloro-3-Omethylnorlichexanthone (minor or major), 5,7-dichloro-3O-methylnorlichexanthone $( \pm$ minor), thiophanic acid $( \pm$ minor), isoarthothelin ( \pm minor), 3-O-methylthiophaninic acid ( \pm trace). See also Kantvilas (1988).

This is a common and widespread species in wet eucalypt forest, rainforest and wet scrub where it occurs on trunks and twigs with smooth bark, including the dead canopy twigs of eucalypts. The concentration of chemical substances in this lichen is rather variable. For example, the occurrence of pannarin, which is often a diagnostic substance easily detected by spot tests (it reacts $\mathrm{P}+$ orange), is very patchy, and is often best detected in the whitish pruina of young apothecia. Although relatively infrequently collected, this species is likely to be widespread in eastern Australia.

Selected specimens examined: TASMANIA: South Sister near summit, $41^{\circ} 32^{\prime} \mathrm{S} 148^{\circ} 10^{\prime} \mathrm{E}, 800 \mathrm{~m}$ alt, 10 .xi.2004, J.A. Elix 28633 \& $G$. Kantvilas (CANB, HO); Pelion Plains, $41^{\circ} 50^{\prime} \mathrm{S} 146^{\circ} 03^{\prime} \mathrm{E}, 850 \mathrm{~m}$ alt., 13.iii.1992, G. Kantvilas

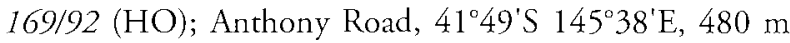
alt., 30.iv.1993, G. Kantvilas 221/93 (HO); Yarlington Tier, $42^{\circ} 32^{\prime} \mathrm{S} 147^{\circ} 18^{\prime} \mathrm{E}, 620 \mathrm{~m}$ alt., 28.x.1987, G. Kantvilas 143/87 (HO); West of Tahune Bridge in the Warra SST, $43^{\circ} 06^{\prime} \mathrm{S} 146^{\circ} 41^{\prime} \mathrm{E}, 180 \mathrm{~m}$ alt., 23.v.2006, G. Kantvilas $245 / 06$ (HO); Dee Lagoon, $42^{\circ} 16^{\prime} \mathrm{S} 146^{\circ} 36^{\prime} \mathrm{E}, 690 \mathrm{~m}$ alt., 15.xi.1964, G.C. Bratt 1801 \& J.A. Cashin (HO); Florentine Road, $42^{\circ} 28^{\prime} \mathrm{S} 146^{\circ} 30^{\prime} \mathrm{E}, 240 \mathrm{~m}$ alt., $10 . x \mathrm{x} .2005$, G. Kantvilas 310/05(HO); Lonnavale, 42 $51^{\circ} \mathrm{S} 146^{\circ} 47^{\prime} \mathrm{E}, 70$ m alt., 28.vi.1964, G.C. Bratt 13596 \& J.A. Cashin (HO); Sandspit River, 42 $42^{\prime} \mathrm{S} 147^{\circ} 50^{\prime} \mathrm{E}, 180 \mathrm{~m}$ alt., 30.x.1988, A. Moscal 16846 (HO); Kangaroo (Lenah) Valley, 9.xi.1899, W.A. Weymouth 952 (HO). Watchorns Hill, Huon Road, $1600 \mathrm{ft}$ alt., 25.i.1899, W.A. Weymouth 674 (HO).

\section{Lecidella sublapicida (Knight) Hertel, Mitt. Bot} Staatssamml. München 199: 444-445 (1983)

Thallus areolate, whitish to cream-white to olive-grey; apothecia scattered, basally constricted, black, mostly to $0.5 \mathrm{~mm}$ wide; hymenium colourless, with epihymenium greenish, unchanged in $\mathrm{K}, \mathrm{N}+$ red; hypothecium orangebrown, intensifying orange in $\mathrm{K}$ and $\mathrm{N}$; ascopsores ellipsoid, $8.5-15 \times 5-8 \mu \mathrm{m}$. Containing vicanicin and several xanthones; thallus C+ orange. See Rambold (1989) and Knoph (1990) for further descriptions.

Although the genus Lecidella remains poorly known in Tasmania, this widespread Australasian species is wellcharacterised by the presence of vicanicin. It occurs on a variety of rock types, mostly in lowland, open sites in heathland and open eucalypt forest.

Specimens examined: TASMANIA: South Sister, lower slope near car park, 41 $32^{\prime} \mathrm{S} 148^{\circ} 10^{\prime} \mathrm{E}, 750 \mathrm{~m}$ alt., 10.xi.2004, G. Kantvilas 419/04 \&. J.A. Elix (HO); near

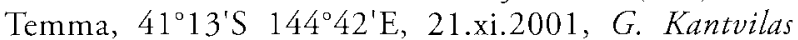

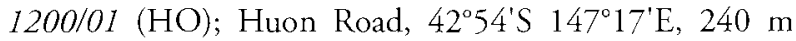
alt., 30.xii.2000, G. Kantvilas 570/00 (HO); Couta Rocks, $41^{\circ} 10^{\prime} \mathrm{S} 144^{\circ} 41^{\prime} \mathrm{E}, 9 . x \mathrm{i} .1993, G$. Kantvilas $304 / 93$ \& I.A. Elix (HO).

\section{Lepraria eburnea J.R. Laundon, Lichenologist 24: 331 (1992)}

Thallus leprose, whitish, greenish to somewhat yellowish, lacking marginal lobes. Containing alectorialic acid, atranorin $( \pm)$ and barbatolic acid ( \pm ); thallus $\mathrm{K}-, \mathrm{KC}+$ fleeting reddish, $\mathrm{C}$-, P+ yellow to orange. See Laundon (1992) for further data.

This is a widespread, pan-temperate species that occurs in shaded underhangs, usually over bryophytes or directly on bark or rock. It is characterised unequivocally by its chemistry.

Specimens examined: TASMANIA: southern slope of South Sister, $41^{\circ} 32^{\prime} \mathrm{S} 148^{\circ} 10^{\prime} \mathrm{E}, 640 \mathrm{~m}$ alt., 31.viii.2006, $G$. Kantvilas 322/06 \& 325/06 (HO); Weindorfers Forest, $41^{\circ} 38^{\prime} \mathrm{S} 145^{\circ} 56^{\prime} \mathrm{E}, 820 \mathrm{~m}$ alt., 28.iii.1988, G. Kantvilas $61 / 88$ (BM, HO).

\section{Micarea denigrata (Fr.) Hedl., Bih. K. Svenska Vetensk.-Akad. Handl. III, 18(3): 78, 89 (1892)}

Thallus areolate or, more commonly, endoxylic and inapparent; apothecia convex to subglobose, to $0.5 \mathrm{~mm}$ wide, immarginate, dark grey to black, $\mathrm{C}+$ red in section; upper part of hymenium with an olivaceous or greyish, $\mathrm{C}_{+}$ violet, $\mathrm{K}+$ violet pigment; ascospores ellipsoid, sometimes curved, (0-) 1-septate, 9-16 × 3-4 $\mu \mathrm{m}$. See Coppins (1983) for full description.

This species is widespread in the temperate northern hemisphere (Coppins 1992a) and occurs on wood, including 
milled timber. The genus Micarea is very diverse in Tasmania, and contains many undescribed or unrecorded species. Spore morphology and the combination of reactions in $\mathrm{C}$ and $\mathrm{K}$ distinguish this species from other superficially similar Tasmanian taxa.

Specimens examined: TASMANIA: southern slope of South Sister, $41^{\circ} 32^{\prime} \mathrm{S} 148^{\circ} 10^{\prime} \mathrm{E}, 640 \mathrm{~m}$ alt., 10.xi.2004, $G$. Kantvilas 389/04 J.A. Elix (E, HO); Daley Property, at the "camp ground", 42 21'S 147\%48'E, $210 \mathrm{~m}$ alt., 24.x. 1004 , G. Kantvilas 248/04 (E, HO).

\section{Mycoblastus campbellianus (Nyl.) Zahlbr., Catal.} Lich. Univ. 4: 3 (1926)

Thallus crustose, whitish, cream or greyish, sorediate; soralia white, $0.2-0.5(-1.2) \mathrm{mm}$ wide, initially discrete, specklike or sometimes tuberculate, soon becoming diffuse or confluent and spreading unevenly across the thallus; apothecia $0.3-0.5(-0.7) \mathrm{mm}$ diam., scattered, \pm superficial, basally constricted, strongly convex and top-shaped when well developed, glossy black to blue-black, rarely dark reddish brown or piebald, immarginate; in section with bright cinereorufa-green pigment (sensu Meyer \& Printzen 2000), \pm unchanged in $\mathrm{KOH}, \mathrm{N}+$ crimson, in the excipulum and upper part of hymenium; asci 2(-4)-spored; ascospores ovate to broadly ellipsoid, $27-51(-56) \times 17-29(-32) \mu \mathrm{m}$, $0(-1)$-septate. Containing perlatolic acid, virensic acid, hyperperlatolic acid and protocetraric acid $( \pm)$; medulla and soralia K-, C-, KC-, P+ orange-red, UV+ white. See Galloway (1985) for full description.

The genus Mycoblastus in the southern hemisphere is currently under revision and will be treated in detail elsewhere (Kantvilas, unpubl.). Mycoblastus campbellianus is a particularly distinctive species, characterised by the combination of a sorediate thallus containing virensic acid ( $\mathrm{P}+$ orange-red), and apothecia with blue-green, "cinereorufa-green" pigment. It is widespread in cool to cold parts of the southern hemisphere, including New Zealand, Tasmania, Campbell Island, Staten Island, Tierra del Fuego and southern Chile, usually as an epiphyte in wet scrub or forest.

Selected specimens examined: TASMANIA: South Sister, $41^{\circ} 32^{\prime} \mathrm{S} 148^{\circ} 10^{\prime} \mathrm{E}, 760 \mathrm{~m}$ alt., 22.xi.2007, G. Kantvilas 369/07 (HO); Little Fisher River, 41 ${ }^{\circ} 45^{\prime} \mathrm{S} 146^{\circ} 20^{\prime} \mathrm{E}, 880$ m alt., G. Kantvilas 437/84 e P.W. James (BM, HO); Lake Dobson, 4241'S 146'35'E, $1030 \mathrm{~m}$ alt., 13.viii.1981, G. Kantvilas 652/81 ef P.W. James (BM, HO); Blue Peaks, $41^{\circ} 43^{\prime} \mathrm{S} 146^{\circ} 23^{\prime} \mathrm{E}, 1290 \mathrm{~m}$ alt., 20.xi.2006, G. Kantvilas 416/06 (HO); Long Tarns, $41^{\circ} 47^{\prime} \mathrm{S} 146^{\circ} 21^{\prime} \mathrm{E}, 1270 \mathrm{~m}$ alt., 24.xi.2006, G. Kantvilas 405/06 (HO).

\section{Mycoporum antecellens (Nyl.) R.C. Harris, More Florida Lichens: 67 (1995)}

Thallus crustose, thin, often whitish, UV-; perithecia abundant, black, $0.2-0.4 \mathrm{~mm}$ wide, unilocular, with wall brown, intensifying yellow-brown in $\mathrm{KOH}$; ostiole central; asci 8-spored; pseudoparaphyses highly branched and anastomosing; ascospores relatively large, 27-40 × 8-14 $\mu \mathrm{m}$, ellipsoid, 1(-3)-septate, hyaline but turning brownish with age. See Coppins (1992b) (as Arthopyrenia) for further data.

This species is widespread on smooth bark in the temperate woodlands of Europe and North America (Coppins 1992b) and has also been recorded from New Guinea (Aptroot et al. 1997). In Tasmania, it has been recorded from trees with smooth bark (Nothofagus cunninghamii, Pittosporum bicolor,
Banksia marginata, Atherosperma moschatum and Tasmannia lanceolata) in sclerophyll forest, wet scrub and rainforest. It may well be quite widespread but is small, inconspicuous and therefore easily overlooked.

Specimens examined: TASMANIA: Meetus Falls, $41^{\circ} 57^{\prime} \mathrm{S}$ $147^{\circ} 53^{\prime} \mathrm{E}, 510 \mathrm{~m}$ alt., 16.v.1989, G. Kantvilas 188/89 (HO); E of Lake Leake, $42^{\circ} 01^{\prime} \mathrm{S} 147^{\circ} 55^{\prime} \mathrm{E}, 400 \mathrm{~m}$ alt., 24.iv.1996, G. Kantvilas s.n. (HO); Savage River Pipeline at 11.5 mile peg, $41^{\circ} 20^{\prime} \mathrm{S}, 145^{\circ} 16^{\prime} \mathrm{E}, 440 \mathrm{~m}$ alt., 9.xii.1993, G. Kantuilas $287 / 93$ \& J.A. Elix (HO); South Sister, $41^{\circ} 32^{\prime} \mathrm{S}$ $148^{\circ} 10^{\prime} \mathrm{E}, 800 \mathrm{~m}$ alt., 10.xi.2004, G. Kantvilas 395/04 \& J.A. Elix (HO).

\section{DISCUSSION}

\section{Diversity and flora values}

The lichen floras of Tasmania's mountains have been sampled and studied in a cursory and opportunistic way, especially in the past 25 years, leading to the discovery and description of many species new to science, and the identification of many new records for Tasmania (for example, see various publications by the authors, cited by McCarthy (2008)). However, very few locations have been subjected to rigorous study and analysis. Exceptions include an account of the alpine flora of southwest Tasmania (Kantvilas 1995), and a survey of Mount Sprent, a Precambrian peak in southwest Tasmania, by Kantvilas \& Jarman (1991). No inventory data exist for any dolerite peaks in Tasmania, nor for any area in northeast Tasmania, and thus the results presented here are very much a pioneering benchmark.

With 234 taxa, in comparison to 141 at Mount Sprent (Kantvilas \& Jarman 1991) and 981 in the whole of Tasmania (McCarthy 2008), the diversity of lichens at South Sister is undeniably impressive. The significant numbers of new records for Tasmania also suggest the area is "special". However, these findings need to be considered against the backdrop of only limited information from elsewhere, that many of the new records are of highly cryptic taxa not easily detected without very thorough searching, or represent species that were already known to the authors from other sites but not formally recorded in the literature for various reasons. Nevertheless, these considerations should not detract from the fact the site supports several very unusual, uncommon and highly restricted lichens.

Noteworthy components of the lichen flora fall into two broad categories. Firstly, there are species that constitute significant range extensions of otherwise not uncommon species. These include Sagenidium molle, which is almost exclusively a species of closed rainforest and occurs mainly on old Nothofagus trees; its presence at South Sister, in sheltered rock crevices, is highly unusual. There are also three primarily alpine species present: Arthroraphis citrinella var. citrinella, Ochrolechia androgyna and Pertusaria flavoexpansa. Although these lichens are common in alpine areas of Tasmania, their occurrence at South Sister represents a considerable extension of range. Like $S$. molle, these species probably represent relicts from a time when the vegetation and microclimate were considerably moister and cooler.

The second category of noteworthy records comprises genuinely rare species. Three of these, Coccocarpia erythroxyli, C. pellita and Xanthoparmelia canobolasensis, were nominated for inclusion on the register of rare and threatened flora under the Tasmanian Threatened Species Protection Act 1995 
and, although meeting all the criteria set down under the guidelines, were not listed (see http:/www.southsister. org).

Coccocarpia erythroxyli: This species is widespread in tropical areas of the world (Arvidsson 1983) and Tasmania represents its southernmost geographical penetration. It is found mostly in remnant wet scrubby forest dominated by Notelaea ligustrina, usually surrounded by dry sclerophyll vegetation, and as such is typically at high risk from fire. At most sites, it is represented by only a few tiny, scattered thalli, sometimes confined to a single host tree. It is locally very abundant at South Sister (pl. 3).

Coccocarpia pellita: This species is widely distributed in tropical and subtropical regions of the world (Arvidsson 1983) and, like the preceding species, its discovery in Tasmania represents the most southerly occurrence of this species in the world. It grows on rocks in sclerophyll forests but is never common, being represented at best by a few isolated thalli.

Lecanactis sp.: This is almost certainly a new species, closely related to the common rainforest epiphyte, L. abietina (Ach.) Körber, but differing by its yellowish leprose thallus containing schizopeltic, lecanoric and porphyrilic acids. It grows on rocks in sheltered crevices and underhangs, and has also been collected at Den Hill, southeastern Tasmania. It is clearly a very rare species, not treated in the revision of the genus for Tasmania by Kantvilas (2004).

Pertusaria barbatica: This is a very distinctive, epiphytic, isidiate, crustose lichen, known from only one other locality in Tasmania (in a remnant Melaleuca ericifolia swamp in the North-West). It also occurs on the southeastern Australian mainland (Archer 1997).

Pertusaria subdactylina: This bipolar species is known in Australasia only from Tasmania, where it has been recorded previously only twice: from Cape Barren Island and $\mathrm{Mt}$ Cameron (Kantvilas \& Elix 2008). Both of these records are from granite; the South Sister collection is the first from living bark (of Cyathodes glauca).

Punctelia transtasmanica: This very uncommon species was not tecorded during a statewide survey of the family (Kantvilas et al. 2002) and is known elsewhere only from Flinders Island (where it is locally common) and a single locality in New Zealand.

Xanthoparmelia canobolasensis: This species is very rare on the Australian mainland, being known only from the Orange area of New South Wales. It was the focus of a conservation study there (D. Eldridge, unpubl.) and has been listed under the NSW Threatened Species Conservation Act 1995. In Tasmania, it has also been recorded near Falmouth. Specific searches for further populations have not been successful.

\section{Threats}

Threats to lichens in a Tasmanian context have been discussed by Brown et al. (1994) and Kantvilas (2000), highlighting habitat destruction (through clearing and other changes in land management) and fire as being of greatest importance in the natural environment. For non-vascular plants, fragmentation of continuous tracts of natural vegetation is also an important factor that has been widely recognised and quantified, particularly in Europe (Coppins \& Coppins 2002). The broad-scale environment of South Sister, although natural, has been subjected to human activity and fire for a considerable period of time, and so can hardly be considered

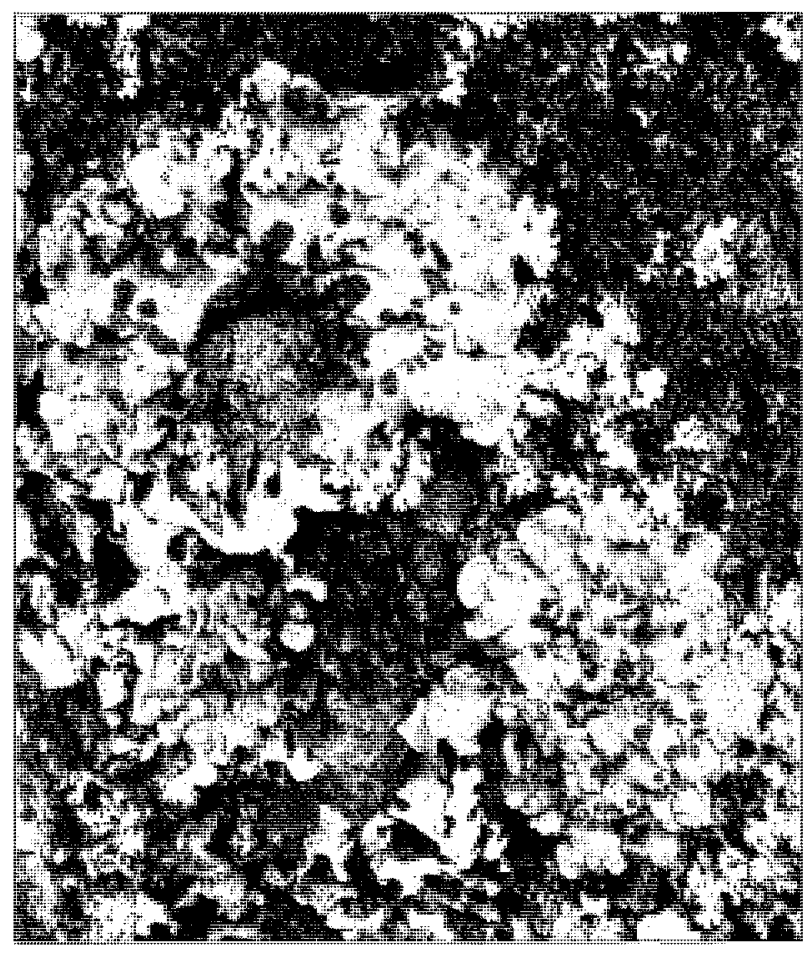

PLATE 3

Coccocarpia erythroxyli, an epiphytic species locally abundant in wet scrub.

"virgin". However, localised parts of the site, such as the rock scree, tors and pockets of wet scrub, where no useable forest products occur and where fire protection is greatest, are for all intents and purposes "pristine". These are the microhabitats where most of the lichens of greatest scientific or conservation interest are to be found.

One noteworthy but previously undocumented threat in the natural Tasmanian landscape, and one that is dramatically evident at South Sister, is the impact of toxic metals leaching from galvanised structures. This effect was first brought to our attention by Tim Rudman (pers. comm.) who observed it at Devils Gullet (northern Tasmania). The impact on the lichen flora can be dramatic, not least at South Sister. At the smallest scale, such as under pipes and fences, the result can be the total elimination of all lichens (pl. 4). On a larger scale, such as around buildings, there is a wholesale replacement of the natural lichen associations, dominated by species of the Parmeliaceae and crustose lichens such as Ramboldia petraeoides and Lecanora farinacea, by associations generally connected with pollution and nutrient enrichment. Here the dominant species are Acarospora veronensis and Lecanora polytropa. Given the patchy occurrence of many of the more interesting and rarer lichen species, the impact of galvanised structures and the resultant metal pollution on the flora values of the site could be critical.

\section{Epilogue: the bushfire of December 2006}

The South Sister area was burnt by a severe and extensive bushfire in early December 2006 (seehttp://www.southsister. org/articles $7 /$ fire 3 . htm for images and details). The study site was revisited in November 2007 to ascertain the impact of the fire on the lichen flora.

In general, fires affect the lichen flora by either causing loss or damage to lichen macrohabitat (e.g., vegetation 


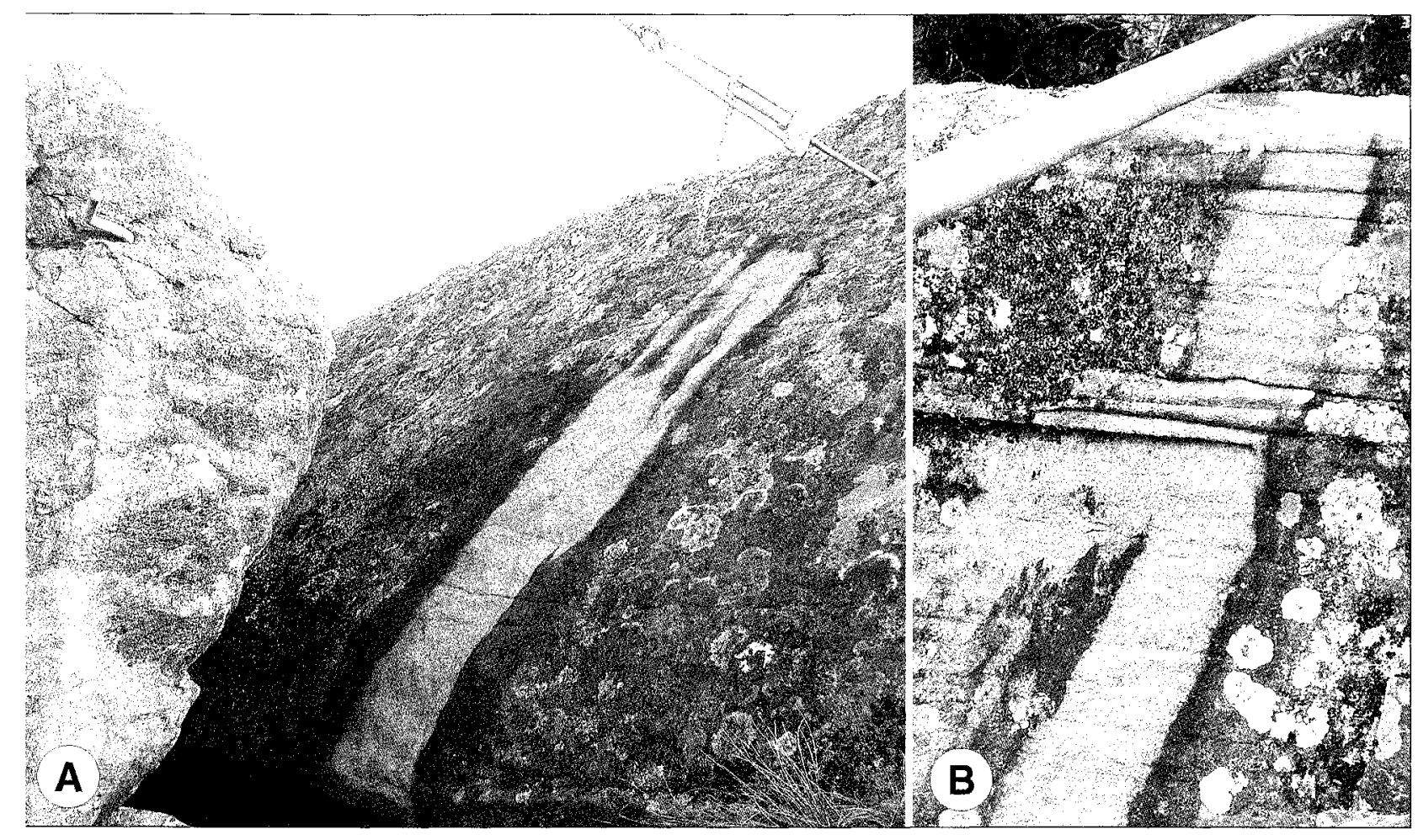

PLATE 4

The impact of galvanised steel on lichens. (A) Band of lichen death in the drip zone and run-off beneath a cable (right) and even beneath a small bolt (left). (B) Detail of the band of lichen death beneath a galvanised pipe.

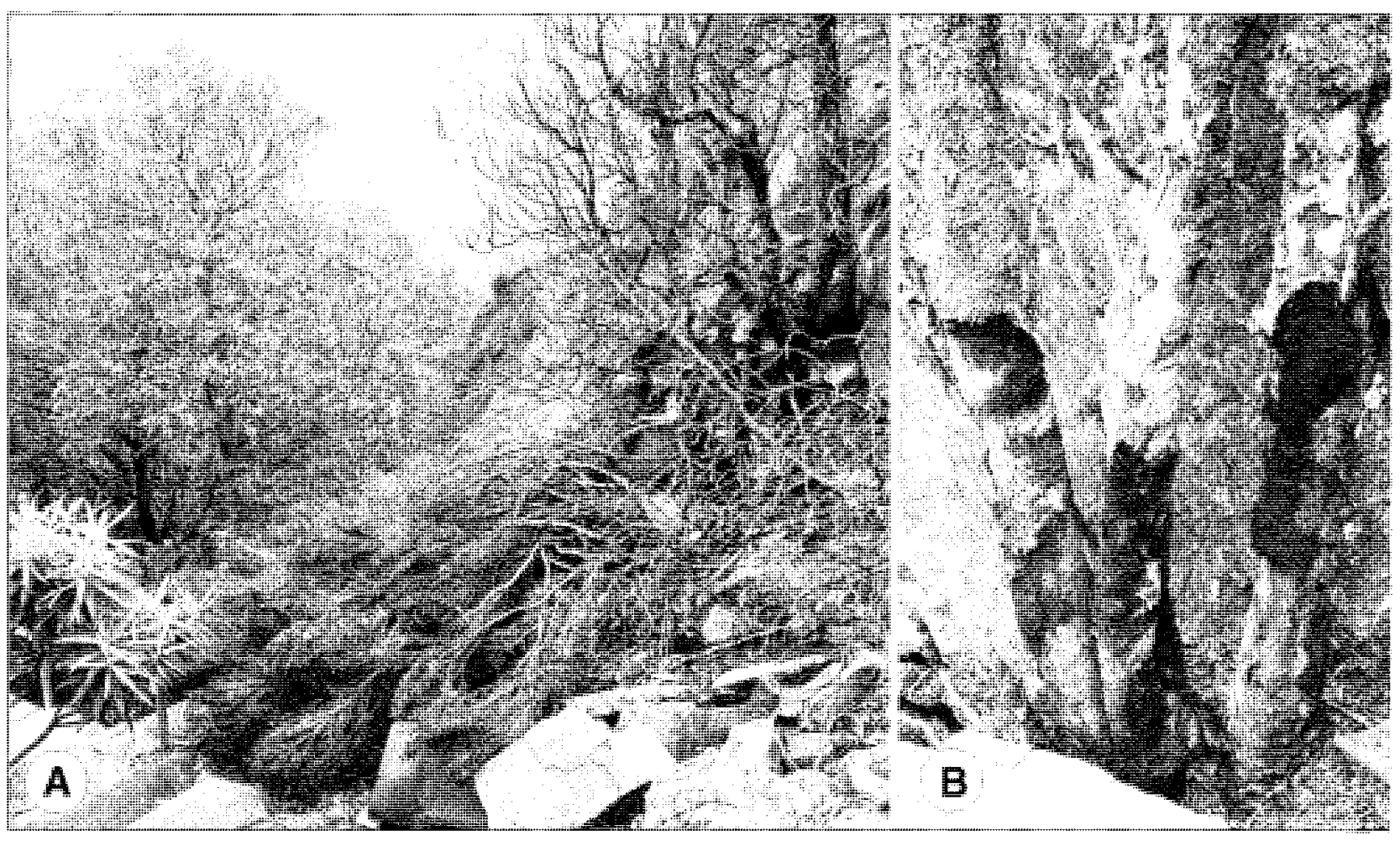

PLATE 5

Effects of the 2006 bushfire. (A) Adjacent patches of burnt (right) and unburnt (left) scrub on rock scree. (B) Mosaic of burnt and unburnt epiphytic lichens and mosses on a single multi-stemmed tree. The intense black patches on the stems are charcoal residues. 
communities), by causing loss or damage to lichen substrates (e.g., particular trees and shrubs) or by direct incineration of the lichens themselves. The South Sister fire, at least in the environs of the pinnacle itself, appears to have been relatively patchy. The eucalypt forest on the lower slopes has been extensively burnt, but this vegetation probably supported the least number of lichens. Damage to the rock scree and tors has been minimal, and the flames seemingly "trickled" through the scrub patches, burning some and scorching others, but also leaving areas untouched (pl. 5). The long-term effect on this scrub, which supported a very significant proportion of the lichen flora, is that it will be even more fragmented than before, more prone to drying out, and therefore also more vulnerable to future fires. Some of the impacts on the lichens only become evident over a longer period of time. Our experience elsewhere indicates that following even a patchy fire, attrition of some lichen species continues as they gradually respond to increased exposure to light and dryness, to smoke or heat damage, or to damage to their host. However, given that extensive unbutnt lichen habitat remains at South Sister, and that all the main habitat types are still well represented, it is highly likely that the composition of the lichen flora, as recorded before the fire, remains unaltered, and that the special flora values conveyed by the lichens are intact, albeit in a more fragmentary and vulnerable state.

Two of the rarest species, Coccocarpia pellita and Xanthoparmelia canobolasensis, were not located after the fire. These species had been recorded on the drier, more exposed northern slopes of the peak where the fire was most severe.

\section{ACKNOWLEDGEMENTS}

We thank Drs Helmut Mayrhofer and Josef Hafellner (Graz) for identifying Illosporium carneum, Dr Brian Coppins for confirming the identity of Micarea denigrata, and the curators of the Queensland Herbarium and other herbaria cited for the loan of type and critical specimens. We also thank Julia Weston for her hospitality during our first visit to South Sister, and to other members of the local community through whose encouragement this survey has been brought to publication.

\section{REFERENCES}

Aptroot, A., Diederich, P., Sérusiaux, E. \& Sipman, H.J.M. 1997: Lichens and lichenicolous fungi from New Guinea. Bibliotheca Lichenologica 64: 1-220.

Archer, A.W. 1997: The lichen genus Pertusaria in Australia. Bibliotheca Lichenologica 69: 1-249.

Arvidsson, L. 1983. A monograph of the genus Coccocarpia. Opera Botanica 67: 1-96.

Brown, M.J., Kantvilas, G. \& Jarman, S.J. 1994: Conservation and reservation of non-vascular plants in Tasmania, with special reference to lichens. Biodiversity and Conservation 3: $263-278$.

Coppins, A.M. \& Coppins, B.J. 2002: Indices of Ecological Continuity for Woodland Epiphytic Habitats in the British Isles. British Lichen Society, London: $36 \mathrm{pp}$.

Coppins, B.J. 1983: A taxonomic study of the lichen genus Micarea in Europe. Bulletin of the British Museum (Natural History), Botany 11: 17-214.
Coppins, B.J. 1992a: Micarea Fr. (1825). In O.W. Purvis, B.J. Coppins, D.L. Hawksworth, P.W. James \& D.M. Moore (eds): The Lichen Flora of Great Britain and Ireland. Natural History Museum Publications, London: 371-384.

Coppins, B.J. 1992b: Arthopyrenia Massal. (1852). In O.W. Purvis, B.J. Coppins, D.L. Hawksworth, P.W. James \& D.M. Moore (eds): The Lichen Flora of Great Britain and Ireland. Natural History Museum Publications, London: $88-92$.

Coppins, B.J. \& James, P.W. 1979: New or interesting British lichens III. Lichenologist 11: 27-45.

Elix, J.A. 2006: A new species of Hafellia (Physciaceae, lichenized Ascomycota) from Australia. Australasian Lichenology 59: 36-38.

Elix, J.A. \& Kantvilas, G. 2005: A new species of Punctelia (Parmeliaceae, lichenized Ascomycota) from Tasmania and New Zealand. Australasian Lichenology 57: 12-14.

Etayo, J. \& Marbach, B. 2003: Hafellia alisioate and H. gomerana (lichenized Ascomycetes, Physciaceae), two new species from the Canary Islands, with a key to all known corticolous species. Lichenologist 35: 369-375.

Galloway, D.J. 1985: Flora of New Zealand Lichens. P.D. Hasselberg, Government Printer, Wellington: $662 \mathrm{pp}$

Hafellner, J. 1984: Studien in Richtung einer natürlicheren Gliederung der Sammelfamilien Lecanoraceae und Lecideaceae. Beiheft zur Nova Hedwigia 79: 241-371.

Hawksworth, D.L. 1981: The lichenicolous Coelomycetes. Bulletin of the British Museum (Natural History), Botany 9: 1-98.

Kantvilas, G. 1988: A re-examination of John Shirley's collection of Tasmanian lichens. Papers and Proceedings of the Royal Society of Tasmania 122(2): 59-67.

Kantvilas, G. 1995: Alpine lichens of Tasmania's south-west wilderness. Lichenologist 27: 433-449.

Kantvilas, G. 2000: Conservation of Tasmanian lichens. Forest Snow and Landscape Research 75: 357-367.

Kantvilas, G. 2004: A contribution to the Roccellaceae in Tasmania: new species and notes on Lecanactis and allied genera. Symbolae Botanicae Upsalienses 34(1): 183-203.

Kantvilas, G. \& Elix, J.A. 2007: Additions to the lichen family Agyriaceae Corda from Tasmania. Bibliotheca Lichenologica 95: 317-333.

Kantvilas, G. \& Elix, J.A. 2008: Additions to the lichen genus Pertusaria in Tasmania. Sauteria 15: 249-263.

Kantvilas, G., Elix, J.A. \& Jarman, S.J. 2002: Tasmanian Lichens: Identification, Distribution and Conservation Status. I. Parmeliaceae. Australian Biological Resources Study, Canberra, and the Tasmanian Herbarium, Hobart: $274 \mathrm{pp}$.

Kantvilas, G. \& Jarman, S.J. 1991: Lichens and bryophytes of the Tasmanian World Heritage Area. I. Mount Sprent. In M.R. Banks, S.J. Smith, A.E. Orchard \& G. Kantvilas (eds): Aspects of Tasmanian Botany - A tribute to Winifred Curtis. Royal Society of Tasmania, Hobart: 149-162.

Knoph, J.G. 1990: Untersuchungen an gesteinsbewohnenden xanthonhaltingen Sippen der Flechtengattung Lecidella (Lecanoraceae, Lecanorales) unter Berücksichtigung von aussereuropäischen Proben exklusive Amerika. Bibliotheca Lichenologica 36: 1-183.

Laundon, J.R. 1992: Lepraria in the British Isles. Lichenologist 24: $315-350$.

McCarthy, P.M. 2008. Checklist of the Lichens of Australia and its Island Territories. Australian Biological Resources Study, Canberra. Version 31 January 2008. hetp://www.anbg. gov.au/abrs/lichenlist/introduction.html.

Marbach, B. 2000. Corticole und lignicole Arten der Flechtengattung Buellia sensu lato in den Subtropen und Tropen. Bibliotheca Lichenologica 74: 1-384.

Meyer, B. \& Printzen, C. 2000: Proposal for a standardized nomenclature and characterization of insoluble lichen pigments. Lichenologist 32: 571-583. 
Nordin, A. 2000: Taxonomy and phylogeny of Buellia species with pluriseptate spores (Lecanorales, Ascomycotina). Symbolae Botanicae Upsalienses 33 (1): 1-117.

Orange, A., Coppins, B.J. \& Scheidegger, C. 1992: Buellia de Not. (1846). In O.W. Purvis, B.J. Coppins, D.L. Hawksworth, P.W. James \& D.M. Moore (eds): The Lichen Flora of Great Britain and Ireland. Natural History Museum Publications, London: 129-137.

Orange, A., James, P.W. \& White, F.J. 2001: Microchemical Methods for the Identification of Lichens. British Lichen Society, London: $101 \mathrm{pp}$.

Øvstedal, D.O. \& Lewis-Smith, R.I. 2001: Lichens of Antarctica and South Georgia. A Guide to their Identification and Ecology. Cambridge University Press, Cambridge: 411 pp.
Purvis, O.W. \& James, P.W. 1992: Acarospora Massal. (1852). In O.W. Purvis, B.J. Coppins, D.L. Hawksworth, P.W. James \& D.M. Moore (eds): The Lichen Flora of Great Britain and Ireland. Natural History Museum Publications, London: 59-63.

Rambold, G. 1989: A monograph of the saxicolous lecideoid lichens of Australia (excl. Tasmania). Bibliotheca Lichenologica 34: 1-345.

Sheard, J.W. 1992: The lichenized ascomycete genus Hafelliat in North America. Bryologist 95: 79-87.

Timdal, E. 1984: The genus Hypocenomyce (Lecanorales, Lecideaceae) with special emphasis on the Norwegian and Swedish species. Nordic Journal of Botany 4: 83-108.

(accepted 24 May 2008)

\section{APPENDIX 1}

Inventory of lichens from South Sister (numbers in parentheses refer to the unique collection number of a reference specimen in $\mathrm{HO}$ ).

* indicates a new record

+ indicates a lichenicolous fungus.

Acarospora sp. (GK 300/06)

*A. veronensis A. Massal.

Arthonia ilicina Taylor

Arthothelium ampliatum (C. Knight \& Mitten) Müll. Arg.

*A. macounii (G. Merr.) W.J. Noble

Arthroraphis citrinella (Ach.) Poelt var. citrinella

*Australecia antarctica Hertel

Bacidia sp. (GK 377/04B)

${ }^{*} B$. wellingtonii (Stirt.) D.J. Galloway

Baeomyces heteromorphus Nyl. ex C. Bab. \& Mitten

Belonia uncinata P.M. McCarthy \& Kantvilas

Buellia sp. (GK 354/07)

${ }^{*} B$. griseovirens (Turner \& Borrer ex Sm.) Almb.

Bullatina microcarpa (Vezda) Brusse

Bunodophoron insigne (Laurer) Wedin

B. patagonicum (C.W. Dodge) Wedin

Calicium adspersum Pers. subsp. australe Tibell

C. tricolor F. Wilson

Caloplaca sp. (GK 301/06)

Candelariella vitellina (Hoffm.) Müll. Arg.

Catillaria sp. (GK 314/06)

C. tasmanica Räsänen

Catillochroma pulverea (Borrer) Kalb

Chaenothecopsis savonica (Räsänen) Tibell

Chiodecton colensoi (A. Massal.) Müll. Arg.

C. montanum Thor

Chrysothrix sulphurella (Räsänen) Kantvilas \& Elix

Cladia aggregata (Sw.) Nyl.

C. inflata (F. Wilson) D.J. Galloway

C. schizopora (Nyl.) Nyl.

Cladonia chlorophaea (Flörke ex Sommerf.) Spreng.

C. confusa R. Sant.

C. corniculata Ahti \& Kashiw.
C. gracilis (L.) Willd. subsp. tenerrima Ahti

C. cf. macilenta Hoffm.

C. merochlorophaea Asahina

C. ochrochlora Flörke

C. pleurota (Flörke) Schaer.

C. pyxidata (L.) Hoffm.

C. ramulosa (With.) J.R. Laundon

C. rigida (Hook.f. \& Taylor) Hampe var. rigida

C. sarmentosa (Hook.f. \& Taylor) C.W. Dodge

C. scabriuscula (Delise) Nyl.

$C$ subsubulata $\mathrm{Nyl}$.

C. sulcata A.W. Archer var. wilsonii (A.W. Archer) A.W. Archer

C. verticillata (Hoffm.) Schaer.

Coccocarpia erythroxyli (Spreng.) Swinscow \& Krog

${ }^{*}$ C. pellita (Ach.) Müll. Arg.

Coccotrema cucurbitula (Mont.) Müll. Arg.

C. porinopsis (Nyl.) Imshaug ex Yoshimura

Coenogonitum luteum (Dicks.) Kalb \& Lücking

Collema durietzii Degel.

C. fasciculare (L.) Weber ex F.H. Wigg. var. microcarpum (Müll. Arg.) Degel.

C. flaccidum (Ach.) Ach.

C. glaucophthalmum Nyl. var. glaucophthalmum

C. leucocarpum Hook.f. \& Taylor

C. quadriloculare $\mathrm{F}$. Wilson var. tasmaniae $\mathrm{F}$. Wilson

C. subconveniens $\mathrm{Nyl}$.

Cresponea plurilocularis (Nyl.) Egea \& Torrente

Cystocoleus ebeneus (Dillwyn) Thwaites

Degelia gayana (Mont.) Arv. \& D.J. Galloway

Dibaeis arcuata (Stirt.) Kalb \& Gierl

Dictyonema sericeum (Sw.) Berk.

Diploschistes scruposus (Schreber) Norman

Flavoparmelia haysomii (C.W. Dodge) Hale 
Fuscidea australis Kantvilas var. australis

F. australis var. montana Kantvilas

F. lightfootii (Sm.) Coppins \& James

Hafellia babiana (Malme) Sheard

${ }^{*} H$. subcrassata Pusswald

${ }^{*} H$. xanthonica Elix

Hertelidea eucalypti Kantvilas \& Printzen

H. pseudobotryosa R.C. Harris, Ladd \& Printzen

Hypocenomyce australis Timdal

H. foveata Timdal

${ }^{*} H$. scalaris (Ach.) M. Choisy

Hypogymnia lugubris (Pers.) Krog

H. mundata (Nyl.) Oxner ex Rass.

H. pulverata (Nyl.) Elix

H. subphysodes (Kremp.) Filson var. subphysodes

H. tasmanica Elix

Hypotrachyna revoluta (Flörke) Hale

H. sinuosa (Sm.) Hale

?Icmadophila sp. (GK 261/04)

* Illosporium carneum Fr.

Imshaugia aleurites (Ach.) S.F. Meyer

Lecanactis sp. (GK 324/06)

Lecanora farinacea Fée

L. lugubris (C.W. Dodge) D.J. Galloway

L. polytropa (Ehrh.) Rabenh.

Lecidella sp. A (GK 283/04)

Lecidella sp. B (GK 376/07)

${ }^{*}$ L. pruinosula (Müll. Arg.) Kantvilas \& Elix

${ }^{*}$ L. sublapicida (Knight) Hertel

Leifidium tenerum (Laurer) Wedin

Leioderma pycnophorum Nyl.

Lepraria coriensis (Hue) Sipman

${ }^{*}$ L. eburnea J.R. Laundon

L. lobificans $\mathrm{Nyl}$.

Leptogium tasmanicum $\mathrm{F}$. Wilson

L. victorianum $\mathrm{F}$. Wilson

Loxospora solenospora (Müll. Arg.) Kantvilas

Maronea constans (Nyl.) Hepp

Megalaria sp. (GK 377/04A)

M. grossa (Pers. ex Nyl.) Hafellner

Megaloblastenia marginiflexa (Hook.f. \& Taylor) Sipman

Melanelia subglabra (Räsänen) Esslinger

Menegazzia aeneofusca (Müll. Arg.) R. Sant.

$M$. confusa P. James

M. myriotrema (Müll. Arg.) P. James

M. nothofagi (Zahlbr.) P. James \& D.J. Galloway

$M$. pertransita (Stirt.) R. Sant.

M. subpertusa P. James \& D.J. Galloway

Micarea sp. A (GK 316/06)

Micarea sp. B (GK 361/07)

${ }^{*} M$. denigrata (Fr.) Hedl.

M. intersociella (Stirt.) Coppins

M. micrococca (Körb.) Gams ex Coppins

M. mutabilis Coppins \& Kantvilas

Mycoblastus sp. A (GK 356/04)

Mycoblastus sp. B (GK 334/06)

*M. campbellianus (Nyl.) Zahlbr.

*Mycoporum antecellens (Nyl.) R.C. Harris

Neophyllis melacarpa (F. Wilson) F. Wilson

Nephroma australe Richard

N. cellulosum (Sm. ex Ach.) Ach.

N. rufum (C. Bab.) P. James

Ochrolechia sp. (GK 332/04)

O. androgyna (Hoffm.) Arn.

Opegrapha sp. (GK 394/04)
Opegrapha viridis Pers. ex Ach.

Pannaria sp. (GK 379/04)

P. elixii P.M. Jørg. \& D.J. Galloway

Pannaria farinosa Elvebakk \& J. Fritt. Rasm.

P. microphyllizans (Nyl.) P.M. Jørg.

Pannoparmelia wilsonii (Räsänen) D.J. Galloway

Paraporpidia leptocarpa (C. Bab. \& Mitt.) Rambold \& Hertel

Parmelia cunninghamii Crombie

P. protosignifera Elix \& J. Johnst.

P. protosulcata Hale

P. signifera $\mathrm{Nyl}$.

P. tenuirima Hook.f. \& Taylor

Parmeliella nigrocincta (Mont.) Müll. Arg.

P. thysanota (Stirt.) Zahlbr.

Parmelina labrosa (Zahlbr.) Elix \& J. Johnst.

P. pseudorelicina (Jatta) Kantvilas \& Elix

Parmelinopsis afrorevoluta (Krog \& Swinscow) Elix \& Hale

P. subfatiscens (Kurok.) Elix \& Hale

Parmotrema perlatum (Huds.) M. Choisy

$P$. reticulatum (Taylor) M. Choisy

Peltigera dolichorrhiza (Nyl.) Nyl.

P. polydactyla (Neck.) Hoffm.

Pertusaria barbatica A.W. Archer \& Elix

P. flavoexpansa Kantvilas \& Elix

P. lophocarpa Körber

P. novaezelandiae Szatala

$P$. pertractata Stirt.

P. subdactylina Nyl.

Phaeographis mucronata (Stirt.) Zahlbr.

Phlyctis subuncinata Stirt.

Placopsis cribellans (Nyl.) Räsänen

P. parellina (Nyl.) I.M. Lamb

P. perrugosa (Nyl.) Nyl.

Placynthiella icmalea (Ach.) Coppins \& P. James

Poeltiaria coromandelica (Zahlbr.) Hertel \& Rambold

Polychidium contortum Henssen

Porina constrictospora P.M. McCarthy \& Kantvilas

P. decrescens P.M. McCarthy \& Kantvilas

Porpidia s. lat. sp. (GK 417/04)

Pseudocyphellaria billardierei (Delise) Räsänen

P. crocata (L.) Vain.

P. gilva (Ach.) Malme

P. glabra (Hook.f. \& Taylor) C.W. Dodge

P. multifida (Nyl.) D.J. Galloway \& P. James

P. neglecta (Müll. Arg.) H. Magn.

P. rubella (Hook.f. \& Taylor) D.J. Galloway \& P. James

Psoroma hypnorum (Vahl) S.F. Gray

P. pholidotoides (Nyl.) Trevis.

P. soccatum R. Br. ex Cromb.

Psoromidium aleuroides (Stirt.) D.J. Galloway

Punctelia borreri (Sm.) Krog

P. subrudecta (Nyl.) Krog

P. transtasmanica Elix \& Kantvilas

Pyrenula occulta (C. Knight) Müll. Arg.

Racodium rupestre Pers.

Ramboldia blastidiata Kantvilas \& Elix

R. brunneocarpa Kantvilas \& Elix

R. laeta (Stirton) Kalb, Lumbsch \& Elix

$R$ petraeoides ( $\mathrm{Nyl}$.) Kantvilas \& Elix

R. plicatula (Müll. Arg.) Kantvilas \& Elix

$R$ stuartii (Hampe) Kantvilas \& Elix

Rhizocarpon sp. (GK 416/04)

R. geographicum (L.) DC. 
Rinodina subcrustacea (Müll. Arg.) Zahlbr.

R. thiomela (Nyl.) Müll. Arg.

Sagenidium molle Stirt.

Siphula fastigiata (Nyl.) Nyl.

Stereocaulon corticatulum $\mathrm{Nyl}$.

S. ramulosum (Sw.) Räusch.

Sticta limbata (Sm.) Ach.

Tasmidella variabilis Kantvilas, Hafellner \& Elix var. variabilis

Tephromela atra (Huds.) Hafellner

T. sorediata Kalb \& Elix

Thelotrema lepadinum (Ach.) Ach.

Thysanothecium scutellatum (Fr.) D.J. Galloway

Topeliopsis sp. (GK 422/04)

T. muscigena (Stiz.) Kalb

Trapelia coarctata $(\mathrm{Sm}$.) M. Choisy

T. involuta (Taylor) Hertel

T. lilacea Kantvilas \& Elix

Trapeliopsis colensoi (C. Bab.) G. Schneid.

T. flexuosa (Fr.) Coppins \& P. James

Usnea inermis Motyka

$U$. oncodes Stirt.

U. rubrotincta Stirt.
U. torulosa (Müll. Arg.) Zahlbr.

Xanthoparmelia amplexula (Stirt.) Elix \& J. Johnst.

$X$. australasica D.J. Galloway

$X$ canobolasensis Elix

$X$ congesta (Kurok. \& Filson) Elix \& Hale

$X$ dichotoma (Müll. Arg.) Hale

$X$ digitiformis (Elix \& P. Armstr.) Filson

X. epheboides (Zahlbr.) O. Blanco, A. Crespo, Elix, D.

Hawksw. \& Lumbsch

$X$. isidiotegeta Elix \& Kantvilas

$X$ loxodella (Esslinger) O. Blanco, A. Crespo, Elix, D.

Hawksw. \& Lumbsch

$X$. microcephala Elix \& Kantvilas

$X$. mougeotina (Nyl.) D.J. Galloway

$X$. neotinctina (Elix) Elix \& Johnst.

$X$. notata (Kurok.) Hale

$X$ scabrosa (Taylor) Hale

$X$. segregata Elix \& J. Johnst.

$X$ subprolixa (Nyl. ex Kremp.) O. Blanco, A. Crespo,

Elix, D. Hawksw. \& Lumbsch

$X$ tasmanica (Hook.f. \& Taylor) Hale

$X$. tegeta Elix \& J. Johnst. 